\title{
Benefits and drawbacks of the national and foreign engineering education. Development trends
}

\author{
N.A. Voronova, M.S.Ostapenko \\ Institute of Industrial Technologies and Engineering, Industrial University of Tyumen, Tyumen, \\ Russia
}

\begin{abstract}
Modern education is a factor that determines the development of a person not only as a personality, but also as a well-qualified specialist. The change in the vector of development of state educational standards of higher education contributes to the reform of programs and methods of teaching students. The integration of the educational environment has led to the fact that most countries have adopted the Bologna system of education. It is thus losing the individuality of the educational process. This paper presents the differences between the national and foreign models of education, as well as the general requirements currently imposed on the quality of engineering education. The study was conducted based on a survey among students, teachers, and employees of enterprises. The aim was to determine the level of engineering education, the number of specialists, as well as personal and professional qualities of future employees of enterprises. The results of this research are based on respondents' responses to an online questionnaire. The paper proposes the reconstruction of engineering education based on the scientistific research and the authors' personal opinion, which contributed to the internationalization of science and the creation of international departments, increased mobility, language training, as well as the creation of conditions for non-standard tasks and team-work. The possibility of training students in real projects, which will promote the relationship between universities and enterprises, as well as facilitate the adaptation of students in the workplace in the future, was considered.
\end{abstract}

\section{Introduction}

Higher education is considered a critical factor and essential for the future success of people in modern society [1]. Nowadays, enterprises search for a skilled workforce oriented towards intellectual work and able to embrace high technologies, who will also develop these technologies and implement them in industries. That is why training of well-trained professionals for enterprises and the development of engineering education are policy challenges and priority growth areas for the country's development.

In the 21 st century, people who have definite achievements in their scope of activity and who can use their knowledge and abilities for actual problem solving are deemed to be 
highly trained professionals. Most highly trained professionals are employed indefinite scopes of expertise and have a narrow specialization.

Tatyanenko notes that Russian society has historically been positive towards engineering education, and most of the engineering schools recognized by the world community are successfully operating [2], thereby confirming the potential of Russian engineering education. In the last decade, the programs, norms, and standards of the academic establishment have been undergoing significant changes. All changes and innovations are implemented to improve the quality of education. In her work, Gorshkova [3] notes that a modern engineer must be a researcher, as the originality and nature of engineering activities are directed at the features of modern production. This point of view, which is that the modern and future engineer should be perceived as a researcher, allows turning engineering education to the sphere of mastering the methods of research activity and thereby radically changes the idea of engineering universities.

In his work, Mikhail N. [4] indicates that currently higher education is aimed at the formation of educated people who will have all the necessary competencies to fight in the modern labour market. This accurately describes the current state of the contemporary education environment since it is a competitive approach that contributes to the education of a sought-after engineer.

The novelty of this research lies in the fact that the present education system, or rather the Bologna education system, is undergoing changes that are fixed in the federal educational standards (FES) that are mandatory.

\section{Survey}

To define further development of modern education, we offered students to complete a survey which included three questions:

1. What is the level of engineering education nowadays?

2. Who is the main requestor of qualified engineers?

3. What personal qualities and professional strengths should an engineer should have?

A questionnaire,an empirical method,was used to collect data. The survey was conducted in the form of an anonymous survey. There was one mandatory open question: the place of work or study.

509 people took part in the survey, including:

$>$ Students getting bachelor and master's degrees, 176 respondents

$>$ Faculty members of three universities (Industrial University of Tyumen, Tyumen State University, and UPI named after the first President of Russia B. N. Yeltsin), 174 respondents

$>$ Enterprise employees (PAO Lukoil, PAO Surgutneftegas, PAO Gazprom Neft, Tyumen Battery Plant, PAO Tyumen Motor Builders), who are not only in demand in the Tyumen Region but also actively cooperate with universities, 159 respondents.

These groups of respondents were selected based on the following factors:

$>$ Students, as future employees of enterprises, should understand what requirements the employer imposes for further successful employment

$>$ Faculty members, as well as students, should be aware that organizationshire qualified personnel

$>$ Enterprises must submit the requirements that the graduate will have to meet after getting a bachelor's or master's degree program.

The survey results presented in Figures 1-3 were obtained.

One of the main questions asked to the respondents was about the level of engineering education at present. The results on this question are presented in Figure 1. The data are presented as a composition in percent. 


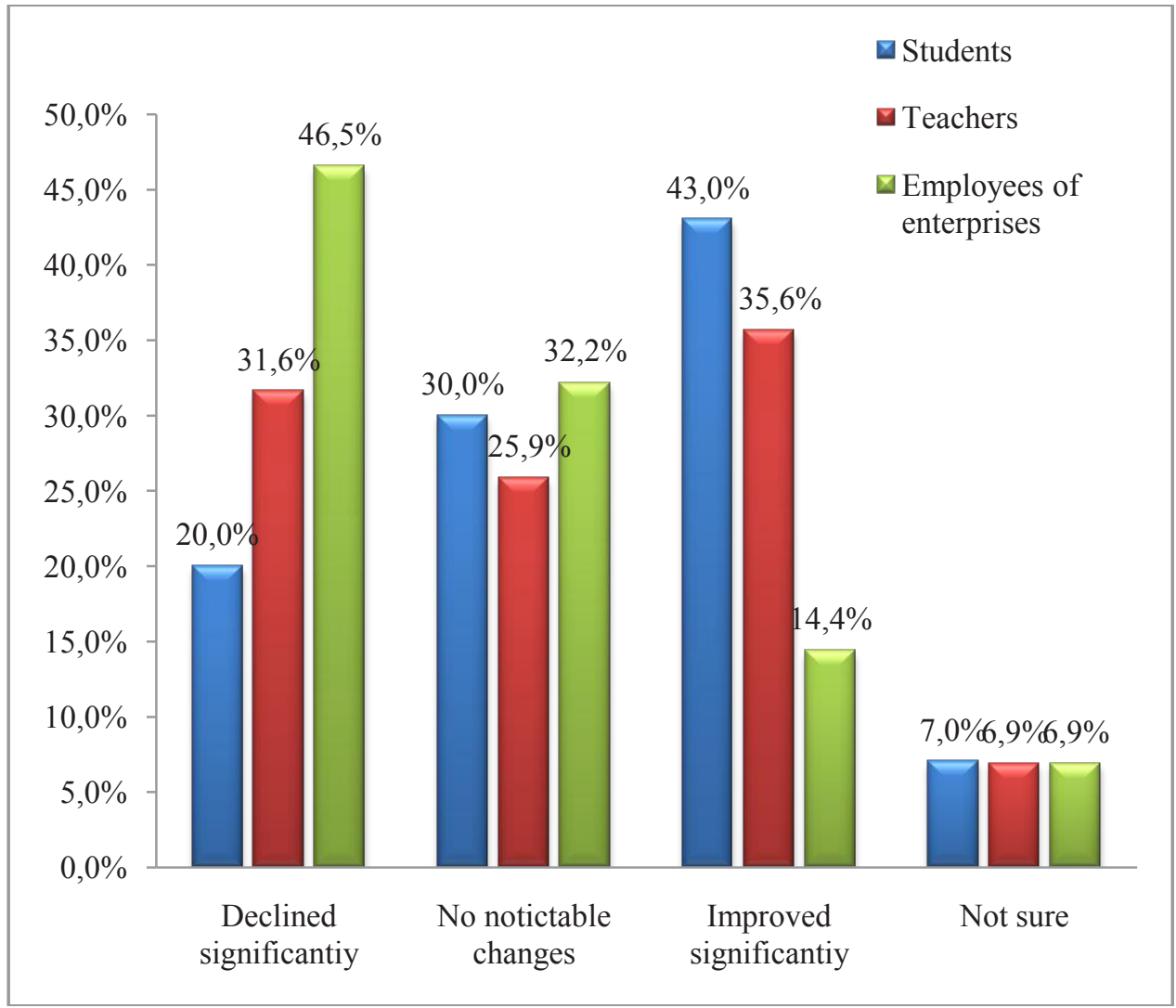

Fig.1. Level of engineering education.

Figure 1 show that the level of engineering education at present, according to employees of enterprises (46.5\%), has deteriorated, as evidenced by the results of the survey. This opinion is also supported by $31.6 \%$ of faculty members. Only $20 \%$ of students studying in undergraduate and graduate programs report a decline in the level of education.

Based on the answers companies' employees, wet can conclude that modern graduates are not ready to face the real problems of enterprises. Students lack practical skills that would contribute to the adaptation process in the workplace.

The question: "Who is the main requestor of qualified engineers?" was meant for a free answer.

Having analyzedthe answers of the students who took part in the survey, we concluded that nowadays the state is the main requestor of qualified specialists. It should be emphasized that due to the change of organizational and legal form, the individual entrepreneur - the organizer of the production process acts as an employer.

The last question posed to respondents was about personal and professional qualities that, according to the survey participants, are in demand in the labourmarket today.

The personal qualities picked by respondents are presented in Fig. 2. 


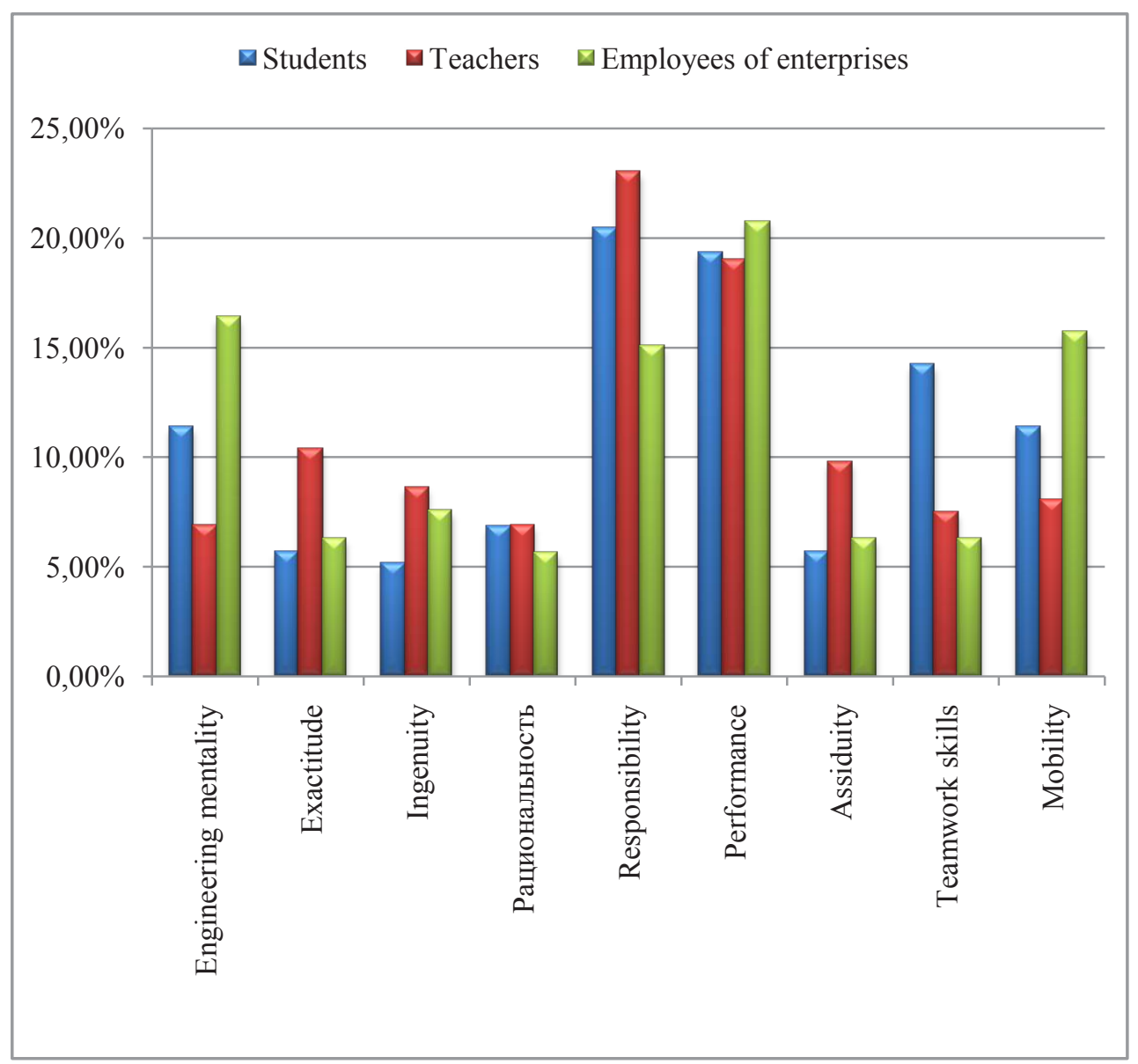

Fig. 2. Personal qualities

It is important to note that the selected personal qualities of students are based on the individual (subjective) opinions of respondents.

Based on the FES, the professional qualities that an engineer should have were identified. A list of professional strengths that a modern engineer should have is presented in Fig.3 


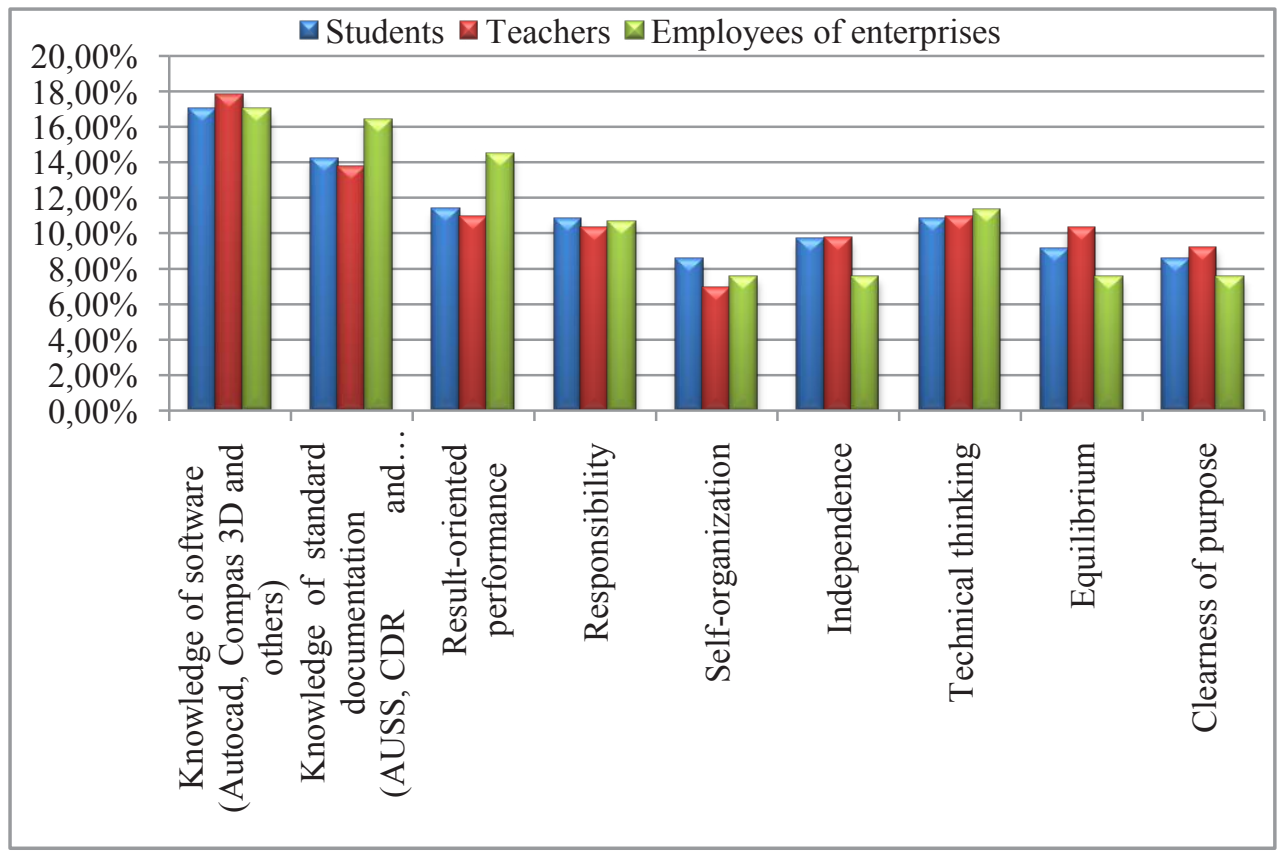

Fig. 3. Professional strengths.

It follows from Fig. 3 that nowadays students pick out four essential qualities that a well-qualified engineer should have:

$>$ Knowledge of the software (Autocad, Compas 3D, and others)

Technical thinking

$>$ Knowledge of standard documentation (AUSS, CDR, andothers)

$>$ Professional responsibility.

The diagram also shows that employees of enterprises distinguish "Results Orientation" since this quality is one of the most important when solving problems in practice.

According to the respondents, if a specialist has personal qualities and professional strengths which are presented in Figures 2 and 3, then he/she will be in demand on the job market. But also worth mentioning is that the professional strengths and personal qualities of university students do not always correspond to the requirements of future employers.

This survey has shown that if the level of engineering training, the development of professional strengths and personal qualities required for work in different areas, as well as cooperation with customers - employers, universities can train future engineers who will be in demand on the job market.

When answering these questions, we picked out several necessary changesin engineering education in several spheres: internationalisation of science and creation of international departments, enhancement of mobility, language proficiency, and also the conditions for solving non-standard tasks and teamwork.

\section{Domestic and foreign education}

The following is an analysis of the literature related to the two educational environments: domestic and foreign (Bologna system). This analysis allowed us to identify not only the positive and negative aspects of educational systems but also the possibilities of remodeling of engineering education. 
The systems of education throughout the world are undergoing reform due to global changes in society, the transformation of political systems, and other socio-economic factors [5].

During an analysis of the two education systems, we picked out the benefits and drawbacks of the national and foreign education systems, which are presented in Table 1.

Table 1. Benefits and drawbacks of the national and foreign (Bologna) education systems

\begin{tabular}{|l|l|l|l|}
\hline \multicolumn{2}{|c|}{ National education system } & \multicolumn{2}{c|}{ Bologna education system } \\
\hline \multicolumn{1}{|c|}{ Benefits } & \multicolumn{1}{|c|}{ Drawbacks } & \multicolumn{1}{c|}{ Benefits } & \multicolumn{1}{c|}{ Drawbacks } \\
availability and & $\begin{array}{l}\text { Brain drain and other } \\
\text { losses of academic } \\
\text { staff under the influ- } \\
\text { ence of ideology and } \\
\text { political fight }\end{array}$ & $\begin{array}{l}\text { Enhancement of the lev- } \\
\text { el and allure and availa- } \\
\text { bility of European high- } \\
\text { er education }\end{array}$ & $\begin{array}{l}\text { General mess includ- } \\
\text { ing thess in aca- } \\
\text { demic programs dur- } \\
\text { ing period of } \\
\text { the } \\
\text { process }\end{array}$ \\
\hline $\begin{array}{l}\text { Access to education } \\
\text { for all racial and lin- } \\
\text { guistic minorities }\end{array}$ & $\begin{array}{l}\text { Low quality of for- } \\
\text { eign language teach- } \\
\text { ing. }\end{array}$ & $\begin{array}{l}\text { The orientation of de- } \\
\text { grees and qualifications, } \\
\text { given by universities, to } \\
\text { the job market }\end{array}$ & $\begin{array}{l}\text { Risks of losses of } \\
\text { educational expe- } \\
\text { rience in the history } \\
\text { of nationalhigher } \\
\text { education }\end{array}$ \\
\hline $\begin{array}{l}\text { High level of train- } \\
\text { ing. High quality of } \\
\text { higher engineering } \\
\text { education }\end{array}$ & $\begin{array}{l}\text { Blackening of pre- } \\
\text { soviet historical pe- } \\
\text { riod, deformation of } \\
\text { moral guides }\end{array}$ & $\begin{array}{l}\text { High level of students } \\
\text { and lecturing staff. Acti- } \\
\text { vation of international } \\
\text { exchanges betweenuni- } \\
\text { versities }\end{array}$ & $\begin{array}{l}\text { Practical incapability } \\
\text { of some innovations } \\
\text { of the process }\end{array}$ \\
\hline $\begin{array}{l}\text { Satisfying the re- } \\
\text { quirements of a state } \\
\text { for a new labour } \\
\text { force when there was } \\
\text { a sharp rise of indus- } \\
\text { try, creation of new } \\
\text { spheres, appearance } \\
\text { of new engineering } \\
\text { spheres. }\end{array}$ & $\begin{array}{l}\text { Doubtful quality of } \\
\text { liberal education be- } \\
\text { cause of the ideologi- } \\
\text { cal bent }\end{array}$ & $\begin{array}{l}\text { Opportunities for uni- } \\
\text { versities to take part in } \\
\text { projects sponsored by } \\
\text { European institutions }\end{array}$ & $\begin{array}{l}\text { Decrease of higher } \\
\text { education level be- } \\
\text { cause of the orienta- } \\
\text { tion on a narrowly fo- } \\
\text { cused specialist in the } \\
\text { prejudice of funda- } \\
\text { mental training which } \\
\text { develops analytical } \\
\text { and critical thinking }\end{array}$ \\
\hline
\end{tabular}

As shown in Table 1, generality was the uppermost achievement of national education, which helped to achieve almost universal literacy for the first time in the history of Russia. Also, it is worth mentioning that job placement was ensured to all graduates of universities because the demand of the state for qualified specialists was very high.

Having analyzedthe national system of education, we concluded that the USSR created one of the best education systems, and due to that the Soviet education pattern rated high not only at home but also abroad.

At the end of the last millennium, European ministers in charge of higher education initialized a set of far-reaching reforms that are known as the Bologna Process. Today, 48 countries participate in this endeavor, which has harmonized higher education systems across Europe, to enhance the competitiveness, mobility, and employability of their students [6].

The development of modern society has led to Russia'stransition to the Bologna education system since 2003. As a result, Russia has reached a new level and continued to compete inthe market of educational services.

The Bologna education system implements such goals as:

$>$ Expanded access to higher education;

$>$ Enhancement of not only the quality of training but also of students and teachers mobility; 
Guarantee of successful job placement of university graduates [7].

But as a national pattern of training, the Bologna system has benefits and drawbacks presented in table 1. One of Bologna system's benefits is that this system is oriented on that students get a set of skills present on the real job market.

From all that has been said, it follows that the USSR created one of the best educational systems, which was gradually replaced the Bologna educational system.Bologna which allowed importing new components to higher education, such as:

$>$ Orientation on the real jobmarket;

$>$ Mobility ofstudents;

$>$ Use of innovative educationalmethods.

The transition from the Soviet educational system to the foreign one (Bolognamodel) contributed to: the attraction of new cohorts (international students), new technologies, and modes of learning.

The Bologna process has already led to the appearance of lots of reforms in the Russian education system, and consequently, it provided a basis for further innovations.

Opportunities for students to develop and actualize real projects or take part in them to get the necessary experience and professional strengths should be the further stage of engineering education development.

One of the tendencies of engineering development is education using real projects. But ac- cording to Klochkov [8], "It is not possible to develop a single strategy for all universities; however, having analyzed the programs of universities, we can outline major development directions."

Nowadays, most of universities transfer to project education. Working on real projects promotes the development of professional skills that are in demand on the job market. Also, the project approach encourages the training of staff for the industry.

As a rule, during the six years of education (four-year Bachelor's degree plus two years of the Master's degree), a student has to take part in 4 to 10 real projects and get accurate results [9]. Thisapproach should be used in higher school, but with the involvementof tasks from the industry which are relevant today. Training students with the use of real projects will help a graduate to get a set of skills necessaryfor further work in a chosen sphere of activitywhen getting a job. Thanks to this approach to education, there will not be a "gap" that exists today between graduates and enterprises, because when hiringan employer suggests thata graduate forget everything he/she studied at university.

To determine respondents' opinions about education using real projects, we asked a question:"Would you like to take part in real projects during your training at university?" According to the results of the survey, we received data presented in Figure 4. 


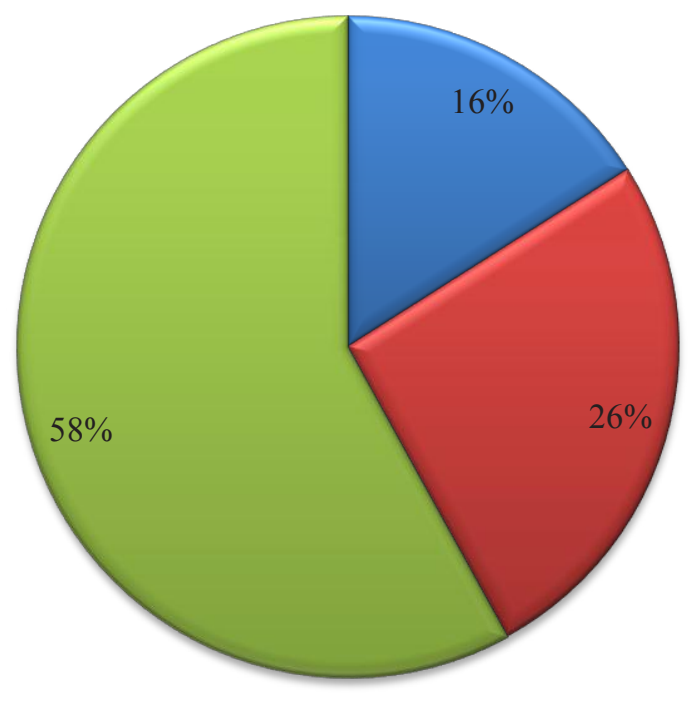

$\square$ Yes

唯o

$\square$ Not sure

Fig. 4. The answer of respondents to the question"Would you like to take part in real projects during education at the university?"

From Fig. 4 we can see that $58 \%$ of respondents have answered in the affirmative, $26 \%$ do not want to take part in projects, and $16 \%$ are neutral.

Real-world project-based learningwill focus the student's attention not only on analyzing aproblem, but also on researching and finding solutions, which will be the initial step in the transition to further education. While studying a problem that exists in industries, students will gain knowledge consciously. Also, using an inter-and multi-disciplinary approach, students will not only gain independent understanding but they will also be able to use and focus itin the process of solving a specific problem.

Also, training based on real projects will promote the creation of a whole chain of "research - design - technology - production - bringing to a consumer - provision of operation," which a modern graduate should not only use but create on his/her own.

\section{Conclusion}

The main conclusion that can be made is that the quality of education has improved and this was facilitatednot only by the change of the education model but the understanding of students that if they get professional skills, they will be in demand on the job market. As in the USSR, the state is the main customer of well-qualified specialists, and it promotes the development of educational services. The transfer to the Bologna model of education contributed tothe development of the Russian education system. It also made it possible to create a new approach to education - engineering education through real projects.

Engineering education using real projects can be considered as an upcoming trend of training because it promotes conduction not only of problem-based research but gives means to solve the tasks set. This approach to training will promote development not only of students but also of industries; it will also sharpen the "gap" between requirements of employers and abilities of graduates because each enterprise will teach and train future workers through projects which exist in industries. 


\section{References}

1. M. C. Felgueiras, J. S. Rocha, N. Caetano Engineering education towards sustainability,(2017)

2. S. A. Tatyanenko Textbook as a mechanism for managing the cognitive activity of a student. From innovation to quality of education: a collection of scientific works. Tyumen, 270-278(2011)

3. O.O. Gorshkova Features of modern engineering education in Russia,13-16 (2016)

4. M. N. Dudin, V. V. Bezbakh, E. E. Frolova, M. V. Galkina The Models of Higher Education in Russia and European Countries at the beginning of the XXIst century: the Main Directions of Development,7(4), 653-667(Academic Publishing House Researcher s.r.o., 2018)

5. E. Y. Levina, M. V. Voronina, A.A. Rybolovleva, M. M. Sharafutdinova, L. F. Zhandarova, V. V. Avilova. The Concepts of Informational Approach to the Management of Higher Education's Development,11(17), 9913-9922 (LOOK Academic Publishers., 2016)

6. J. J. W. Powell, N.Bernhard, L. Graf The Emergent European Model in Skill Formation: Comparing Higher Education and Vocational Training in the Bologna and Copenhagen Processes. Sociology of Education 2012,85(3), 240-258 (2012)

7. N.A.Voronova, M.S.Ostapenko Comparison of Bologna and soviet educational systems: benefits and draw-backs, 462, 15-18(Publishing company: Publishing company "KnoRus" Ltd., 2019)

8. Y. S. Klochkov Monitoring Centre for Science and Education, (2016)

9. A.I.Borovkov, S.F.Burdakov, O.I. Klyavin, M.P.Melnikova, V.A.Palmov, E.N. Silina Modern engineering education,80, 52 (The Publishing House of Polytechnic University, 2012) 